\title{
Uniqueness of History Sudden Rise and Rapid Fall Of Taliban in Afghanistan
}

\author{
Dr. Parvez Ahmad \\ ASSOCIATE PROFESSOR OF POLITICAL SCIENCE \\ Govt. Post GRAduAte EMERSon College Multan, PaKistan
}

\begin{abstract}
The phenomenon of Taliban is very old but they emerged as rulers in Afghanistan in 1994. Afghan Taliban were different kind of people because they were the production of a very typical environment. They were deprived of International Politics and modern knowledge. They were all Pashtoon-sunni of hanfi fiqah and fond of war because they were non-expert in the traditional occupations of their forefathers. They emerged as a result of warlordims and terrible situation of civil war. The public support was with them because they controlled law and order with iron hand. Their policies were very harsh so they implemented Islamic laws according to their own thinking. After capturing Kabul and other parts of the country, they opened all the roads, disarmed the population. They raised their finances from drug trade, transport business and external aid. Their harsh policies, shelter for Osama Bin Laden and signing of contract for construction of gas pipeline to 'Bridas' (Argentina Oil Company) offended the U.S.A. The incident of 9/11 provided an opportunity, so the whole world was standing by America and the Taliban's rapid downfall was inevitable because it was the competition of traditional people and weapons with modern people having super technology. Taliban did not accept the technical domination of U.S.A instead, they accepted rapid downfall of their regime. So they decided to carry out their historical resistance against the foreign invaders at all cost.

Key Words: Warlord-local Commander, Mulla-Religious teacher, Stinger-portable Missile, Unocal-American Oil Company, Gowadar-Pakistani port, Al-Qaeda-Terrorist organization
\end{abstract}

\section{Taliban:}

In Arabic language, the word 'Talib' indicates its meaning' represent the meaning, ii Seeker of religious knowledge as a students studying in (Religious Institution) Madrassa. The term "Taliban" is the plural form of Talib that means "a student in a traditional Islamic educational institute (Madrassa)". Madarassa is a typical system of Islamic education in which almost the poor people's children get religious education free of cost. The Taliban live on the charity of the community. The Madarssas attracted a large number of people as Taliban aspired by the reputation and scholarly qualification of Maulvi (Mulla, religious teacher) in typical Afghan society. During the long course of war (Jehad) against U.S.S.R, the rural areas of Afghanistan had remained largely outside the control of the Kabul regimes and influence of Soviet Union. During the occupation of soviet forces on Afghanistan in 1979, ${ }^{\mathrm{iii}}$ a number of small Madarassas were developed as a reaction to communism which raised the Taliban as well as Mujahideen strength that had always been a feature of traditional rural society. "There were around 2500 spiritual teachers and leaders enjoying a vital leadership role in the village and tribal society of Afghanistan before the failed attempt to introduce communist ideology in Afghanistan." ${ }^{\text {,iv }}$ The Madarassas became the sanctuaries of freedom fighters. These Taliban were the backbone of the Jehadi forces and nobody can ignore the role of Taliban in the defeat of Soviet Union, even the Soviet Union policy makers could not visualize such kind of resistance in Afghanistan. Almost all the Afghan Jehadi parties' leadership was vested in the hands of religious people who were the teachers of Taliban in one or the other form. It is worth mentioning that during the Jehad years, the similar phenomenon was adopted in Pakistan by the Afghan refugees which played the role of nursery for Majahideen organizations. A large number of afghan refugee orphans got admission in the Madarasas of Balochistan, NWFP and Tribal Areas because they had the same culture and language so they felt no difficulty in adopting these Madarasas. ${ }^{\mathrm{v}}$ President Zia allowed these Madarassas for gaining political ends and satisfying the religion oriented people who were his actual supporters. These Madarasas were funded by the Islamic organizations as charity from different Islamic countries. Two religious political parties of Pakistan, Jamiat-ulullama-i-islam and Jamaat-Islami established Madarasas in the provinces of Balochistan and NWFP (Now KPK) to achieve the political ends. They provided Shelter to the orphans of Afghan Jehad and also provided training camps to fight against communist Soviet Union. ${ }^{\text {vi }}$ These two organization especially and some other small religious organizations also earned a lot in the name of these Madarasas from Islamic donor organizations and from the western countries also. General Zia-ul-Haq favoured these religious organizations and political parties both for the cause to fight against Russians along with securing support for his non elected government. He 
killed the two birds with one stone. Professor Ahmad Hasan Dani said that the Taliban received their Education in Pakistan where they were being prepared for Jihad against those people who would not stick with the moral code of Islam. ${ }^{\text {vii }}$

\section{Soviet Union's Withdrawal and Establishment of Majahideen Government in Kabul}

After the withdrawal of soviet forces (1988) from Afghanistan, the Americans started disengaging themselves from the afghan problem. They were only interested in ousting the Soviet Union and they used the Pakistani and the Afghan Majahideen for this purpose. As usual, America left Afghanistan before the final settlement of new government in Kabul. United States did not break her past record in this regard. Before leaving Afghanistan, their only objective was to collect the unused stinger missiles which were in the hands of different Majahideen groups. "One day they told us that their mission-getting the bear out of Afghanistan-was accomplished, and they were now only interested in retrieving the still unused stingers ${ }^{\text {viii }}$ (the portable antiaircraft missile).In this situation Pakistan was the only country who was interested in the restoration of peace and stability and friendly government in Kabul. At last with the support of Saudi Arabia, Pakistan succeeded in establishing an exiled interim government of Majahideen alliance on Pakistan soil in Peshawar. With other problems, the problem of Pashtoon and non-Pashtoon was at the top, always crucial in past and remained crucial in future. Pashtoons always ruled the country throughout the history; they cannot accept any non Pashtoon as a ruler. Burhanuddin Rabbani, head of the Jamiat-e-Islami, Afghanistan took the office of president in 1992 after the fall of president Najibullaha. He was Tajik and created Tajik domination in Kabul which was unacceptable for the Pashtoons. It was a devastating psychological blow because for the first time in three hundred years history ${ }^{\mathrm{ix}}$ the Pashtoons had lost control of the capital. The emergence of Taliban was reprisal of Pashtoons. These Taliban Mulla's discussed the prevailing horrible situation and miseries of the people and try to do something for the people of Afghanistan, so God provided them the opportunity.

\section{Establishment of Taliban movement}

"Though the recent phenomenon of Taliban has its roots in the afghan war against the soviets in the 1980's, tradition of Madrassa's has been there since the arrival of Islam in the seventh century and 'Taliban' (students) became an important part of the social fabric: running schools, mosques, shrines, and various religious and social services, and serving as Majahideen when necessary." ${ }^{, \mathrm{x}}$ When Taliban emerged, there was a total vacuum of leadership in the Pashtoon areas as warlordism gripped the South and the Majahideen leadership had failed to unite the Afghan tribes and to control the law and order situation in the whole of Afghanistan. So Taliban faced no possible political challenge because there was no Pashtoon leadership to oppose them. The situation all over Afghanistan was much more horrible than one can be imagine. "Their leaders sold off every thing to Pakistani traders to make money. The warlords seized home and Agri-farms threw out their occupants and handed them over to their supporters. The commanders abused the population at will, kidnapping young girls and boys for their sexual pleasure, robbing merchants in the bazaars and fighting and brawling in the streets." ${ }^{\text {xi }}$ In the smoke of chaos and disorder of Afghanistan after the withdrawal of Soviet Union and afterwards on the failure of interim government, there raised a new movement named "Taliban". Taliban got power under the natural phenomena, 'survival of the fittest'. Compulsorily, someone or the other had to fill this vacuum of power which Taliban did. The Taliban very soon controlled the affairs of the whole of Afghanistan but their way of ruling and policies were condemned by all the countries especially by the U.S and western world.

\section{Birth of Taliban- A Uniqueness}

The Taliban as an independent group appeared on the scene in $1994^{\mathrm{xii}}$ in the area around Kandhar under the leadership of Mulla Omar. The Taliban aroused as a power in response to an incident against the reaction of highway robbery. In July 1994, in a brutal high way robbery, three girls were kidnapped ${ }^{\text {xiii }}$ and raped by a gang of rebel Majahideen group which shook the people of that area because such kind of actions are severely condemned in afghan society. Local people approached Mulla Omar for help and Mulla in turn called on some of his Madrassa students "Taliban" to teach a lesson to the culprits. Mulla Omar recruited thirty students from the religious school of Mainrand who had 16 rifles to rescue ${ }^{\text {xiv }}$ the girls from the kidnappers. This group of Taliban captured the offenders and hung them with the gun barrel of a tank. This kind of punishment was unexpected to this kind of people in that situation of chaos and anarchy. Mulla Omar said, "We were fighting against Muslims who had gone wrong. How could we remain quiet when we could see crimes being committed against women and the poor?" ${ }^{\text {"xv }}$ Certainly, the people of that area were against the power group's activities and waiting for the savior. At this stage of anarchy an ordinary Afghan was looking for a 'Messah' (Saviour) whom they found in the form of Taliban. The formal name to this new born organization was given, "Tahereek-iIslami-i-Taliban Afghanistan.

Masses supported Taliban and gathered around them for a secure future and peace. Taliban did not demand any reward or credit from those they helped. Their sole aim was to set up Islamic system and establish law and 
order. Afterwards these Taliban responded to the calls from the other people of the area when they were called. They punished the rebels and warlords who indulged in anti social activities. The Taliban moment was not pre planned. It rose up as reaction to nip the evil with people's back. But the religious enthusiasm and manpower spreading all over the country provided them idea for the establishment of their government and enforcement of Islamic system. Following that thinking, they began their war against the government forces and rapidly conquered most of the area. Taliban distanced themselves from the party politics of the Majahideen and indicated that they were a movement for cleansing society rather than a party trying to grab power.

\section{Taliban from a small group to rulers}

"We took up arms to achieve the aims of Afghan Jihad and save our people from further suffering at the hands of the so-called Majahideen. We had complete faith in God Almighty. We never forgot that he can bless us with victory or plunge us into defeat", said Mullaha Omar. ${ }^{\text {xvi }}$ The Taliban took the city of Kandhar after two days minor fighting. It was their first victory which encouraged him and opened the way of victories in future. The government forces at garrisons surrendered and the Taliban captured a vast quantity of arms and ammunition. ${ }^{\text {xii }}$ The next months were very important for the Taliban, now they were advancing to occupy other provinces where they captured twelve provinces within a short time of three months. Their strength was increasing day by day; the Afghan refugees and native Pushtoons were joining the ranks of Taliban.

To conquer the capital- a strategic point, a fierce fight took place between the Taliban and Prime Minister's forces, finally Prime Minister Hekmatyar fled away and his forces dispersed. After some months, most of his fighters joined the Taliban but the capital remained under the control of president Rabbani. Still Kabul- the capital was under the control of Rabbani along with Ahmad Shah Masood, Taliban attacked the city and after fierce fights, Masood retreated and vacated the city. Establishing the administration over the country and to control the law and order situation and better rule, the Taliban formed a six member provisional council, all Mullahs, headed by Mullah Omar. Most of the external religious organizations present in Afghanistan began co-operation with Taliban, the most important terrorist organization in the region with the Taliban regime in Afghanistan was Al-Qaeda, led by Osama Bin Laden. Al-Qaeda had evolved into a pivotal force in antiAmerican terrorism in the 1990s. Al-Oaeda moved it's headquarter from Sudan to Afghanistan in early 1997. ${ }^{\text {xiii }}$ In Afghanistan Al-Qaeda received significant support from the Taliban regime because it was a source of hard currency for Taliban. Al-Qaeda trained the volunteers that constituted the spearhead of the Taliban's conventional fighting force.

\section{Taliban Programme}

The Taliban programme was very simple, localized and unexpectedly very effective. They put their hands on the pulse of the afghan nation's problems and their solutions. Taliban established a council under the leadership of Mulla Omar to run the government. There was a four point agenda ${ }^{\text {xix }}$ that provided the nation-a spirit of life and control of central government on the state affairs which was absent till the fall of President Najibullaha.

1-Promised to end the fighting and to restore law and order situation

2-Corrupt commanders will be removed by high-quality commanders

3-All heavy weapons were to be returned over to the Taliban

4- Strongly disapprove and oppose the drug trade

In a nutshell, they started the rescue operation for the war-destroyed Afghan nation. Their programme seemed to be a programme of every Afghani and the war devastated areas. Nobody could oppose their programme due to their control on law and order situation even many groups were against the emergence and philosophy of Taliban. The Majahideen groups who had held monopoly on different parts of the country and warlords could not resist them because their policies were according to the wishes of the people and they also crushed the activities of ant-society bandits.

\section{Pakistan's reaction to Taliban Government}

All Afghan Majahideen organizations except Ahmad Shah Masood and Rasheed Dostum were obliged to Pakistan for its help during the Soviet occupation and on bearing the burden of over three million refugees since their migration in 1979.After the withdrawal of Soviet Union Pakistan had good relations with interim government of Rabbani, the relations went sour in 1994 when president Rabbani refused to step down after the expiry of his term. During this misunderstanding Rabbani government began to turn towards India to show hatred against Pakistan. Now in Afghan power game Pakistan was with those groups who were trying to unseat Rabbani and his supporter Masood. It is interesting that in the beginning Taliban were not the favourates. Pakistan helped Taliban when they established their control on the trade route to central Asian states. Pakistan's interest was in the rehabilitation of the road from Chaman-Kandhar-Herat-Kushka to trade with Central Asian States proceeding to the other neighbouring states to get monopoly in trade. Chaman-Torghundi road ${ }^{\mathrm{xx}}$ is 800 
Kilometer long which would reduce the time between the Chaman on Pak-Afghan border and Torghandi on the Afghan-Turkmanistan border from forty two hours to thirteen hours only. This route became the shortest land route to the Central Asian States which depended on the will of Taliban. Afghans as well as Pakistanis were eager for this trade. So the Taliban-Pakistan interaction started. At the same time, relations between Islamabad and Kabul had reached to its lowest point.

Pakistan's dream for trade, oil and gas pipeline form central Asia to Pakistan through Afghanistan after the demise of Russia went sour due to chaos in Afghanistan. "The Taliban of Afghanistan initially represented a non-state actor of immense potential. It attracted Pakistan's attention in the context of the latter's ambition to seek a diplomatic, commercial and possibly strategic opening into post-soviet central Asia."xxi It was time when Pakistan tried to eat the ripe fruit through trade to Central Asian States but in vain. While already Pakistan was facing the after effects of afghan problem in the shape of drugs, Kalashankov culture and ethnic problems. Presence of three million Afghan refugees due to Civil war in Afghanistan, took away jobs and housing from the local population. These issues were haunting the civil society of Pakistan but the successive change in elected governments could not modify the Pakistan afghan policy. In May 1997, Taliban regime was recognized by Saudi Arabia ${ }^{\text {xxii }}$ and Pakistan.

\section{Administrative Measures Taken by Taliban}

Taliban government maintained law and order situation in the country except on the ten percent area that was under the control of The Northern Alliance. Its credit goes to the Taliban. Their measures were before time because the training needed for these measures had not been made prior to implementation. They imposed strict Islamic codes such as demanding full veiling for women and barring them from work outside their home, closing of girl's schools and shut down of U.N.O relief programme. This programme was for the welfare and reconstruction of Afghan society but the limited thinking of Mullahs could not accept it. They closed the cinemas and banned the musical broadcast on radio and T.V. They advised women to follow Islamic dress codes and ordered the government employees to perform mid day prayers at their workplace. ${ }^{\text {xiii }}$ Videos, satellite dishes, music and all games including chess, football and kite flying were banned. The Taliban's brand of Islamic fundamentalism was of extreme; apparently, it defamed Islam's message of peace, tolerance and its capacity to live with other religious and ethnic groups. They were extremists and refused to compromise with traditional Islamic values, social structure and existing state system. Islamic system strictly imposed by Taliban was not in practice any where in the world. International media paid much attention to Taliban reforms and the code of Islamic punishments. It is a fact that no guarantee were provided to the human rights. Their codes were Islamic in their views but it was not according to the principles of Islam advised in the Quran and Sunnah. Their code was correct to them because their religion thoughts were marked by their social set-up and local conception.

Taliban's orthodox Islamic government and its typical policies were not compatible with the rest of the world. They were not ready to cooperate with the world because of their typical and tribal thinking. From these actions they were sending a terrible message to the world community that made them aloof from the rest of the world. They dynamited the two statues of Buddha ${ }^{\text {xxiv }}$ carved on the cliffs-side in Bomian province, though the different nations especially the Japanese and Sri Lankan governments made requests not to demolish the statues, but the Taliban refused to accept world requests and destroyed them declaring the statues un-Islamic. Buddhism is the religion of the largest community; Taliban irritated the community as well as world on the destruction of great heritage. The two Buddahas, Afghanistan's greatest archaeological heritage had stood for nearly 2000 years and had withstood the assault of the Mangools. It was a crime that could not be justified by any appeals to Islam. Taliban leadership forgot that Islam is a religion of peace and provides all kinds of security to minorities. Prophet of Islam Muhammad (peace be upon him) was a messenger of peace and love and always protect the minorities. In Islamic states, monitories always enjoyed the state protection of every kind.

Taliban's bold act was to capture and beat the former president Najibullah from the UN diplomatic compound, dragged his body behind a jeep and pulled it around the presidential palace and then shot him dead. It was the first symbolic and brutal act of Taliban in the capital which terrorized the people. ${ }^{x v}$ They should adopt the proper procedure so that the justice could be seen according to the teaching of Islam. The act was in-human and got opposition of the whole world.

With all these actions Taliban government was loosing favour around the globe and were supporting and giving training to the terrorist groups. The Taliban were host to extremist groups from central Asia, Iran, Kashmir, China and Pakistan whose militants were fighting for the Taliban. "The world community was equally concerned about Pakistan's connection with Taliban that provided a physical base to transitional Islamic militant networks."xxvi They had become host for extremist groups from all over the world. Due to this reason Taliban remained internationally isolated and condemned by its neighbours. Taliban are strongly opposed to modernism and have no desire to understand or adopt modern ideas of progress or economic development. Every one in the world has refused to accept or compromise with the Taliban political system. 
Taliban in their manifesto declared that they would enforce Islamic laws but they got Zakat on the trade of narcotics and did not try to control the narcotics production and smuggling. Most of the opium was smuggled to Europe and U.S.A. It solved the financial problems of Taliban and their warlords. We cannot push the people to grow wheat as there would be an uprising against the Taliban if we forced them to stop poppy cultivation. So we grow opium to gain good money and from the money we get our wheat from Pakistan ${ }^{\text {xxvii }}$

In 1996, Osama Bin Ladon issued his first declaration of jihad against the Americans at their arrival in Kuwait. In 1997, he came to Kandhar and remained under the protection of Taliban till their downfall. In the beginning, he supported the Majahideen with the help of CIA but Osama changed his path after 1996. Basically he played the role of front man of CIA in the Afghan war. His presence with Taliban terrorized the Americans and ill reputed the afghan government.

\section{United States blunder in Afghanistan and 9/11 Attacks}

United States of America succeeded to expel Soviet Union from the Afghanistan by backing the Afghan Majahideen through Pakistan. United States left Afghanistan (1988) before the final settlement of Afghan crises though, the Majahideen fought America's proxy war only on the payment of billions of dollars. It is a fact that in the war against the Soviet Union not a single American soldier lost his life in Afghanistan. As soon as their aim was achieved the afghan Majahideen were forgotten. The situation in Afghanistan was very crucial because the Majahideen were fighting each other to control the vast area possible because of wardlordism and deteriorated law and order situation. In the worst situation of the society, Taliban emerged to fill the vacuum of power and they succeeded to maintain law and order along with implementing harsh policies. If the U.S had established representative government in Afghanistan then they would not have seen the worst situation in the afghan society and the world in the form of drugs and terrorism.

On 11 September 2001, the world watched T.V coverage of the terrorist xxviii air attacks on twin towers of World Trade Center in New York and on Pentagon in Washington D.C. The sudden news of terrorist attack on America shocked the people all over the world and stunned the American nation. The U.S President G.W.Bush sought to create a greater coalition of nations in support of the U.S in response to any other event. The sudden attack of $9 / 11$ on America changed the international scenario which provided an opportunity to Americans to act according to their planning. Within days after the attack, President G.W. Bush declared that USA would wage a war against the forces of international terror wherever they were found; "Our enemy is a radical network of terrorists and every government that supports them...Our war on terror begins with AlQaeda, but it does not end there. It will not end until every terrorist group of global reach has been found, stopped, and defeated...Every nation, in every region, now has a decision to make. Either you are with U.S. or you are with the terrorists." ${ }^{\text {xxix }}$ Immediately after the attack, U.S approached the government of Pakistan and made seven demands, and that Pakistan needed to decide whether it was with the U.S or against it. The U.S administration was surprised when President Musharf agreed to support the U.S in all the seven points. There was no alternate to it. Pakistan completely reversed the direction, removing its support for Taliban and pledging cooperation with the U.S.A. Pakistan provided assistance to U.S campaign in Afghanistan, 'operation enduring freedom'. The success of U.S campaign would have been impossible without the support of Pakistan. Factually saying that the Taliban government lost the war against U.S on the day when Pakistan decided to provide bases, intelligence information and logistic support to U.S.A. It is important to note that the other neighbouring states offered all kinds of support but the U.S.A was determined to obtain Pakistan's support. "Operation Enduring Freedom" began on October 7, 2001, with the support of a coalition of ninety nations, the largest coalition in world history." $\mathrm{xxx}$

The Americans were seriously terrified on the destruction of the World Trade Centre and Pentagon; these were the symbols of U.S economic and military power. The investigation of this disaster is still a mystery, how these hijackers hijacked the four planes from different airports and flew to their targets and crashed the planes. Where the different concerned authorities were at that time and why these planes were not interrupted by the U.S air force? How did it happen? The answer to this question is still unknown. The American government thundered on the world community and frightened the people by asking, "If you are not with us, you are against us." President Bush alleged Taliban for the terrorist act of 9/11, though none of the hijackers came from Afghanistan. They demanded from the Taliban government in Afghanistan that Osama Bin Laden and other AlQaeda leadership be handed over to U.S government. U.S government accused Osama for this attack but did not provide any evidence against Osama's involvement in this attack which was against the natural justice. Mullah Omar, leader of the Taliban government, asked America for convincing evidence of Osama Bin Loden's involvement which was not provided. Mullah Omar, leader of Taliban refused to accept the U.S demand. He said that this action would be against the principles of Islam, natural justice and the afghan traditions, so he would not hand over Osama as he was a guest of Taliban. We honour our guests and are responsible for their security. 


\section{U.S role in the downfall of Taliban}

No doubt, the attacks of 9/11 on America were very horrible but American reaction against a particular group was immediate and without evidence which created reservations in the minds of the world community. In spite of all the hesitations, the world was standing with America. It was unfortunate for the Taliban to loose the support of world but the people of the third world, especially the Muslims believed in the innocence of Osama so he became the outlaw superstar of the exploited people. President without loosing any time demanded from Taliban to hand Osama Bin Laden over to U.S.A for the trial of 9/11 attacks. It is still a mystery for the world that how the American government reached the prime suspect within moments while they could not escape such important centers having modern and sophisticated system of spies and intelligence. American refused to provide evidence and began preparations for attack on Afghanistan. As a matter of fact, Taliban government decided to face the American threats but refused to hand over Al -Qadea leadership. Taliban had to face the consequences of refusal to U.S.A and that was natural. Basically, the Taliban had no clear idea of the extent of U.S power, considering only that it was much farther away than the Soviet union had been during the 1980s. Taliban leadership forgot that U.S had sophisticated computerized technologically advanced weapons along with navy and air force bases stretched around the world. Taliban had to face the wrath of Americans in the shape of day night bombing for full three months, October to December 2001.U.S forces attacked the Taliban government headquarters, command centers and airfields from airbases and submarines. First of all the US targeted the small Afghan air force which they destroyed on the ground within hours after initiating the attack It was small wonder that none of the states of the whole world was standing with the Taliban. Perhaps it might be the single event in the world history where the whole world was with America or on the single side against the backward afghan nation. Heavy bombardment destroyed the Taliban's command and control centers, their frontlines, battlefields, caves and tunnels. The Taliban were positioning and preparing for land fight against the U.S led forces which they had experienced against the Russian forces. US government did not take the chance/risk of land attack but used their technology and modern weapons to destroy the Taliban forces and military power. During these attacks, U.S government worked out the matter of occupation on Taliban control territory with 'The Northern Alliance'. Now the U.S forces with the support of The Northern Alliance started their land side attack while The Northern Alliance forces captured most of the Taliban areas with the help of U.S forces. Within two months, Taliban had been dispersed and all their regional centers had been vacated the most difficult military campaign in American history. In the background of this war there were other interests for which the whole drama was staged. In 1991, Argentinean oil companies 'Bridas' was the first company which got the lease for exploring oil and gas in ${ }^{\text {xxxi }}$ Turkmenistan. At that time, the famous giant oil companies of the world called it unwise due to the absence of laws for foreign investment protection and marketing to export gas. The head of the 'Bridas' company adopted the idea from Latin American techniques to market the gas through pipeline. The new idea was to export the gas through cross-border pipelines to multiple markets. In 1994, Company's engineers surveyed zigzag Afghanistan within one month's from possible routes to export the gas to China or South Asia. At that time, U.S.A considered this pipeline a ridiculous idea and they showed no interest. Afghanistan was politically under the ruling of three groups, President Rabbani, Taliban, and The Northern Alliance. Chairman 'Bridas' signed an agreement with Afghan government along with the approval from Taliban and warlords for the gas pipeline security. It was a great success in a war-torn country. Before the implementation of this agreement, American company 'Unocal' jumped to control the oil and gas reserves of Turkmenistan with the help of its government. American government supported the 'Unocal' because it prevented him from becoming dependent on Iran. From the day of Islamic revolution, U.S.A and Iran were at daggers drawn. In 1995, 'Unocal'and its partner Saudi owned-Delta oil Company ${ }^{\text {xxxii }}$ signed agreement with the president of Turkmenistan to build a gas pipeline to Pakistan through Afghanistan. Now in this game, big powers had entered. The Taliban conditioned the gas pipeline with the recognition of their government. However, the government of USA refused to accept the demand due to fear of anti-Taliban public opinion. It was very difficult for the US government to go against public opinion. The Taliban could serve the U.S.A by isolating Iran by breaking its monopoly on Central Asian Southern trade routes and by providing security for trade routes and pipelines. In 1999, Taliban shake the interests of U.S in Afghanistan by supporting Osamsa. They refused to endorse the Unocal project and compromise with US opponents and new moderate government in Iran. Unocal reached the conclusion that in the presence of Taliban the project of pipeline could not be carried out. American government considered other options to construct gas pipeline from Caspian to Turkey avoiding Russia and Iran. The Americans did not want to loose the control of 'Great Game' of Central Asian states resources along with the world market of oil. The oil companies were reluctant to use this route due to cost and turbulence (civil wars in Central Asian states) in the region. The pipelines going through Russia and Iran would neither be safe nor economically feasible because any twist of policy in Russia or Iran would block or even sabotage them. Thus, the American benefits could not be secured in Taliban's presence in Afghanistan. So the efforts for the change of Taliban regime became inevitable. Americans could not afford the control of the pipeline in the hands of other than American company. So, the Taliban became the victims of 9/11 incident. 
America with the support of the whole world destroyed the government of Taliban on the name of so-called 'war against terrorism'. Certainly, there was played a great game behind the Taliban downfall which was surely with the intention of control over oil and construction of the pipeline for this purpose. For achieving these short and long term objectives, America contacted the warlords in different areas and the Northern Alliance. The development of relations with these two forces weakened the Taliban government and paved the way for the permanent stay of America in Afghanistan. The Americans decided to use the military way instead of the diplomatic ways to change the Taliban government and crushing the Al-Qaeda organization though, the AlQaeda leadership had been partner in the proxy war in Afghanistan. Al-Qaeda and Taliban government of Afghanistan always declined their role in the 9/11 attacks, in spite of declined their role in attacks they faced the music.

\section{Rapid fall of Taliban}

The sudden collapse of the Taliban came as a surprise. It is a fact that the Taliban regime from its emergence to fall concealed its weakness to the entire world. Their fierce public policies disguised their role in the eyes of public as shaky theocratic regime. So the public was with them on the issue of law and order but against their strict social and political policies. Pakistan's withdrawal of support from the back of Taliban was a major factor of Taliban downfall. Neither America nor Taliban could survive without the support of Pakistan. The conquest or defeat depended on Pakistan for the both parties. For the continuity of war till victory, Taliban had no sanctuaries outside and inside Afghanistan and the NATO forces were confident about the defection of Tabilan into different groups. They were not disciplined troops but a crowd of religious people having little Vision. Their policies against Afghan traditions (anomaly between the Afghan social order and the Taliban system) made them thorough unpopular before the world as well as before the Afghan primitive society.

America's sophisticated technology and its indefinite use forced Taliban to disperse. Before this war of terror, in every war some one or the other country had been supporting the afghan tribes by supplying weapons, techniques of war and training, but this was the only war which was fought alone by the Taliban. There was no chance of Taliban's success. Taliban suddenly vacated Kabul as they had reached the conclusion that they were unable to defend the Whole of Afghanistan particularly the capital in front of super technology and disciplined force. These were lame excuses that they wanted to abstain from civil causalities and would start irregular warfare. Their proposition of warfare seemed non-practical. Taliban avoided the final fruitless combat to avoid complete destruction and to save the remaining forces and assets and to fight long guerilla wars. America successfully attacked Afghanistan with the support of regional forces. The Taliban guerilla war could not succeed because this time the tactics of war had been changed. Afghan people were fighting the war against the single super power and on the other hand there was none of the neighbouring state standing with him. Some of the American interests in Afghanistan were traceable and some were not, yet they have failed to get the objective of invasion clearly because the allied forces are still facing the resistance from the Taliban and other warlords.

Some of the traceable objectives to invade Afghanistan by the U.S.A were: The killing or capturing of $\mathrm{Al}$-Qaeda leadership, change the regime of Taliban to pro- American, control the region through prolonged presence of forces, fight against terrorism and its nurseries and control the hydro-carbon (minerals) sources of central Asian states. All these objectives reflect that USA had both short and long term goals in Afghanistan. It may be their strategy to invade and occupy since the downfall of U.S.S.R. because the only hurdle in their way had now gone. The external involvement remained on surface for long years. The external forces poured money to their affiliated groups to fight for their cause. The Afghanis are habitual of these earnings and involvements in their internal affairs. The US especially paid money to different afghan groups to hire their services to capture the Taliban and Al-Qaeda people but the mission is still in jeopardize. The situation in Afghanistan was not favourable for the construction of gas pipeline from Turkmenistan to the Gowadar port in Pakistan. Before the regime of Taliban, the law and order situation was worse and tribal warlords were ruling their tribal areas independently.

The main strategy of the US was to by-pass Iran and to reduce dependence of the oil routes via Russia. It was the political determinant of US to find a route for the central Asian republic's oil that by-passed both Russia and Iran. Control on oil supply is not a simple Phenomena, it is a direct threat to the security. So its direct control in the hands of America was felt necessary. This control over oil gives America a stronghold over the oil dependent European and Japanese economies. In the near future even china and India will fall in the same category. The control on oil would be turned into a political influence over most economies of the world including developed and developing countries, even the US will influence the oil producing wealthy countries decision making. Since the discovery of oil and invention of internal combustion engine, oil and state policies both internal and external have become inseparable. Dependence on oil has resulted into state revelries. America's war against terrorism and the operation by the United Nations forces led by America in Afghanistan in not other than to control the supplies of oil to the world markets. If the USA, "consolidate a strategic military 
presence in the central Asian republics and so dominates Caspian Basin oil reserves, then it might, through firm control of the global oil spigot, hope to keep effective control over the global economy for the next fifty years. ${ }^{\text {xxiii }}$ There is also a military aspect of oil as well as the economic aspect. "The military runs on oil." The U.S opponent countries have sophisticated weapons but how they would use these sophisticated weapons with out fuel. "The emulation of US consumerism, way of life, cultural forms, and political and financial institutions have contributed to the process of endless capital accumulation globally. ${ }^{\text {xxiv }}$ The U.S provided economic and military protection to political and military elites of different states whenever needed. In return to these protections, the elites (political and military) implemented pro-American policies which were visible and invisible.

The Taliban could not compete the super technology weapons used by the US forces. Finding unable, Taliban suddenly vacated the capital city of Kabul and other big cities step by step. They saved the common afghan from killing and war suffering while most of the infrastructure had been destroyed. The Taliban did not want the destruction inflicted by US led forces because there was no comparison of modern equipment and traditional weapons. The Northern Alliance forces immediately occupied Kabul which was suddenly vacated by Taliban forces. The U.S.A established a new government in Afghanistan under the leadership of a Pashtoon, Hamid Karzai

In these terrible circumstances the credit goes to the Taliban that they faced the modern technology, the whole world's opposition, internal tribal enmity with their untrained forces and disorganized state apparatus. Taliban's resistance to U.S led forces was a great surprise for the world and especially for the Americans. It is important to know that the enemy himself paid tribute to the Afghans which reflect the historical evidence of their bravery. "The Taliban are tough fighters": ${ }^{\mathrm{xxv}}$ said the U.S Secretary of defence. Taliban avoided the final futile combat to let alone from complete destruction and to save the remaining forces and assets and to fight long guerilla war. For achieving these short and ling term objectives, America contacted the warlords in different areas and the Northern Alliance. The development of relations with these two forces weakened the Taliban government and paved the way for permanent stay of America in Afghanistan. The American decided to use the military way than to adopt diplomatic ways to change the Taliban government and crushing the AlQaeda organization though, the Al-Qaeda leadership had been partner in the proxy war in Afghanistan. The most important secret behind the rapid downfall of Taliban was that no world power block or neighbour stood by them.

\section{Conclusion}

The rise of Taliban was purely indigenous in character which was a reaction to the degeneration of the Afghan Jihad into a civil war. There is no evidence of outside support to Taliban for organization and rapid occupation of Afghanistan. It was seen as a positive sign by the native people but the world refused to recognize Taliban's rule due to their style of governance. Their style was incompatible with the requirements of the civilized age. Their extreme religious views, its implementation and their involvement in terrorist activities against international community made them terror and fear for future. After the incident of 9/11, NATO forces inflicted war on Taliban as a revenge of attack on America. This time war was fought between the superior technology and the afghan traditional weapons without the neighboring countries support. Besides this, the International and internal environment was not favourable as it had been in the past so they were unable to fight this multi-front war. Pakistan joined the U.S and became partner in the war against terrorism by taking $\mathrm{U}$ turn leaving the Taliban alone. Taliban's rapid downfall begins from the moment when Pakistan withdrew its support. The allied planes dropped laser guided bomb on the Taliban which crushed the conventional warfare tactics of Taliban. It was the war between modern technology pitched against an ill equipped tribal people. In nutshell, the super modern technology of U.S. and its allies converted an already destroyed state into rubbles. Taliban were armed with conventional weapons and, therefore, it was impossible for them to continue with this war because their enthusiasm and traditional thinking and warfare strategy was no match for the American war strategy. Resistance of Afghans is history proven. Either the Afghans retain their cultural heritage or they would bring an end to the U.S.A's tyranny.

\section{References}

[1]. “Almanjud” Arabic Dictionary,Maulana Muhammad Shafi,Daarualashat,Karachi,1975,p.610 
[2]. Pushto English Dictionary,Dr.Abdul Hamid Bahij,Danish Publishing Association, Peshawar, 2008,p.223

[3]. Rais,Rasul Bahsh,Recovering the Frontier State,Oxford University Press,Karachi,2008,p.90

[4]. Matinuddin, Kamal,The Taliban Phenomenon Afghanistan 1994-1997, Oxford University Press,Karachi,1999,p.13

[5]. Ibid,p.14

[6]. The News, $27^{\text {th }}$ April 1995 ,

[7]. The Muslim,Islambad,21 $1^{\text {st }}$ Feberuary 1995

[8]. Yusuf,Kaniz F,Dr, Unipolar World and The Muslim States,Pakistan Forum,Islamabad Series No .8 ,2004,p.247

[9]. Rashid,Ahmed,TALIBAN-Islam, Oil and the New Great Game in Central Asia,I.B.Tauris Publishers, London, 2001,p.21

[10]. Ibid,p.31

[11]. Ibid,p.21

[12]. Tanner,Stephen Afghanistan, Oxford University Press,Karachi,2003,p.279

[13]. Rashid,Ahmed Op-cit,,p.21

[14]. Yousafzai,Rahimullah,' The Nation', $4^{\text {th }}$ October 1996(Incident occurred July 1994)

[15]. Burns,John and Levis,Steve, New York Times,11th December 1996 ('How Afghanistan' stern rulers took hold

[16]. Yousafzai,Rahimullah The News, $2^{\text {nd }}$ Feberuary 1995

[17]. Tanner,Stephen,Op-cit,p.280

[18]. Hagerty,Devin,T .South Asia in World Politics, Oxford University Press,Karachi,2006,p.284

[19]. Matinuddin,Kamal Op-cit,p.26

[20]. Matinuddin.Kamal,Op-cit,p.63

[21]. Talbot,Ian,(Edited)The Deadly Embrance, Oxford University Press,Karachi,2007,p.153

[22]. Dawn,Lahore, $25^{\text {th }}$ May 1997

[23]. Ballance, Edger O, Afghan Wars ,Oxford University Press,Karachi,2003,p.244 ( Decree announced by General Presidency of Amr Bil Maruf and Nai An Munkar, 1996)

[24]. Musharaf,Parrvaiz,_Op-cit,,pp.214-215

[25]. The Muslim,Islamabad,27 $7^{\text {th }}$ September 1996

[26]. Baxter,Craig,Op-cit,p39

[27]. Rashid,Ahmed, Op-cit,p.118

[28]. On $9^{\text {th }}$ September 2001,T.V networks all over the world displaying the scenes of attacks and destruction of U.S Twin Towers and kidnapping of aeroplanes by the unknown terrorists

[29]. President Bush Address to the Congress and American people on $20^{\text {th }}$ September 2001

[30]. Dawn, $7^{\text {th }}$ October 2001(Code name of attack on Afghanistan)

[31]. Ejaz,Ahmed,United States Policv On Terrorism, Centre for South Asian Studies,University of the Punjab,Lahore,2007,p.120

[32]. Ibid,pp.120-121,117

[33]. Harvy,David, The New Imperialism, Oxford University Press,(New York )Karachi,2005,p.24

[34]. Ibid,p.41

[35]. Yusuf,Kaniz,F,Dr (Edited)Op-cit,p.251 